\title{
TAOK1 wt Allele
}

National Cancer Institute

\section{Source}

National Cancer Institute. TAOK1 wt Allele. NCI Thesaurus. Code C125174.

Human TAOK1 wild-type allele is located in the vicinity of $17 q 11.2$ and is approximately $161 \mathrm{~kb}$ in length. This allele, which encodes serine/threonine-protein kinase TAO1 protein, is involved in the mediation of protein kinase activity and the modulation of signaling. 